\title{
Uji Aktivitas Antibakteri Ekstrak Etanolik Daun Mengkudu (Morinda Citrifolia L.) Terhadap Bakteri Streptococcus Pyogenes secara In Vitro
}

\section{In Vitro Antibacterial Activity of The Ethanolic Extract Of Morinda Citrifolia L. Leaves Against Streptococcus Pyogenes}

\author{
Margareta Retno Priamsari ${ }^{1}$, Almira Rokhana² \\ marga_rhee@yahoo.co.id \\ ${ }^{1}$ Sekolah Tinggi Ilmu Farmasi Nusaputera Semarang \\ 2Politeknik Katolik Mangunwijaya Semarang \\ Riwayat Artikel: Dikirim Juli 2020; Diterima September 2020; Diterbitkan Oktober 2020
}

\begin{abstract}
Abstrak
Faringitis merupakan salah satu penyakit yang termasuk dalam Infeksi Saluran Pernapasan Atas (ISPA). Bakteri yang paling umum pada faringitis akut adalah Streptococcus pyogenes. Tanaman yang memiliki khasiat sebagai antibakteri adalah mengkudu (Morinda citrifolia L.). Penelitian ini bertujuan untuk mengetahui kadar hambat minimal (KHM) aktivitas antibakteri S. pyogenes secara in vitro.

Ekstraksi dengan metode remaserasi menggunakan pelarut etanol 96\%. Pengujian antibakteri dengan metode Kirby-Bauer menggunakan media BAP yang diinokulasikan secara spread plate. Kelompok perlakuan

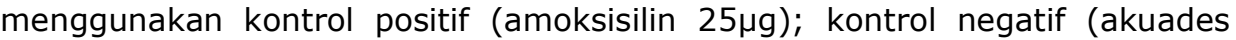
steril); ekstrak daun mengkudu dengan konsentrasi 1,25\%, 2,5\% dan 5\%. Replikasi dilakukan sebanyak 3 kali. Parameter yang diamati adalah zona hambat yang terbentuk disekitar kertas cakram. Data yang diperoleh dianalisis secara statistik menggunakan Kruskall-Wallis dilanjutkan Mann-Whitney dengan taraf kepercayaan 95\%.

Hasil penelitian menunjukkan bahwa ekstrak daun mengkudu mengandung senyawa saponin, triterpenoid, tanin dan fenol. Ekstrak daun mengkudu berpengaruh secara signifikan $(p \leq 0,05)$ terhadap $S$. pyogenes. Konsentrasi 2,5\% memiliki aktivitas terkecil dengan rata-rata diameter zona hambat sebesar 5,83 $\mathrm{mm}$.
\end{abstract}

Kata Kunci : Morinda citrofolia L., S. pyogenes, antibakteri

\begin{abstract}
Pharyngitis is a disease that is included in the Upper Respiratory Tract Infection (ISPA). The most common bacteria in acute pharyngitis is Streptococcus pyogenes. Plants that have antibacterial properties are noni (Morinda citrifolia L.). This study aims to determine the minimum inhibitory level (MIC) of S. pyogenes antibacterial activity in vitro.

Extraction by remaceration method using ethanol $96 \%$ solvent. The Kirby-Bauer method for antibacterial testing used BAP media inoculated by means of a spread plate. The treatment group used a positive control (amoxicillin $25 \mu \mathrm{g}$ ); negative control (sterile distilled water); Noni leaf extract with a concentration of $1.25 \%, 2.5 \%$ and $5 \%$. Replication was carried out 3 times. The parameters observed were the inhibition zone formed around the disc paper. The data obtained were analyzed statistically using Kruskall-Wallis followed by Mann-Whitney with a confidence level of 95\%.
\end{abstract}


The results showed that the noni leaf extract contained saponins, triterpenoids, tannins and phenols. Noni leaf extract had a significant effect $(p \leq 0.05)$ on $S$. pyogenes. The $2.5 \%$ concentration had the smallest activity with an average inhibition zone diameter of $5.83 \mathrm{~mm}$.

Keywords: Morinda citrofolia L., S. pyogenes, Antibacterial

\section{Pendahuluan}

Faringitis merupakan salah satu penyakit yang termasuk dalam Infeksi Saluran Pernapasan Atas (ISPA) (Elliot dkk, 2013). Prevalensi sebanyak $15-30 \%$ pada anak-anak dan 15\% terjadi pada orang dewasa (Khan, 2012 dalam Aini dkk, 2016). Infeksi faringitis terjadi pada osofaring dan nasofaring (Dipiro dkk, 2015). Gambaran klinis dari faringitis yaitu pasien mengalami gatal pada tenggorokan, gangguan menelan dan batuk. Gejala lainnya seperti organ limfoepitelia lateral dinding faring posterior meradang, mukosa kemerahan dan membengkak, demam dan rasa tidak nyaman (Nagel \& Gurkov, 2012). Bakteri penyebab faringitis meliputi Neisseriae, Haemophilus spp., Streptococcus pneumonia (S. pneumonia), Staphylococcus aureus (Staph. aureus), dan Streptococcus pyogenes (S. pyogenes) (Elliot dkk, 2013). Bakteri yang paling umum pada faringitis akut merupakan S. pyogenes. Faringitis dapat diobati dengan menggunakan terapi antibakteri (Dipiro dkk, 2015)

Antibakteri merupakan substansi yang diketahui memiliki kemampuan untuk menghalangi pertumbuhan organisme lain khususnya mikroorganisme (Pratiwi, 2008). Penggunaan antibakteri secara terus-menerus dapat menimbulkan resistensi bakteri. Resistensi terjadi ketika kepekaan bakteri berubah yang menyebabkan turun atau hilangnya aktivitas obat, senyawa kimia atau bahan lain yang digunakan untuk mencegah atau mengobati infeksi (Kuswandi, 2016). Efek samping yang ditimbulkan oleh antibakteri yang kurang cermat dan tepat pemakaiannya dapat merugikan sehingga perlu dilakukan alternatif obat alam untuk mengobati faringitis (Yanti dkk, 2014).

Salah satu tanaman yang memiliki khasiat sebagai antibakteri adalah mengkudu (Morinda citrifolia L.). Penelitian Aryadi (2014), menunjukkan bahwa senyawa pada ekstrak etanolik daun mengkudu pada konsentrasi 10\% dapat menghambat aktivitas bakteri Staph. aureus dengan zona hambat kuat sebesar $16 \mathrm{~mm}$. Zat aktif dalam ekstrak etanolik daun mengkudu yang berperan sebagai antibakteri yaitu saponin, triterpenoid, tanin, dan minyak atsiri seperti fenol (Purba, 2007 dalam Diassanti, 2011).

Daun mengkudu diduga selain dapat menghambat pertumbuhan Staph. aureus juga dapat menghambat $S$. pyogenes. Bakteri Staph. aureus dan $S$. pyogenes merupakan bakteri penyebab faringitis yang termasuk bakteri kokus gram positif, tidak bermotil, tidak berspora dan termasuk bakteri anaerob fakultatif (Elliot dkk, 2013). Berdasarkan latar belakang di atas, maka perlu dilakukan penelitian untuk mengetahui daya antibakteri ekstrak etanolik daun mengkudu terhadap bakteri $S$. pyogenes sebagai alternatif obat faringitis.

\section{Metode Penelitian}

Alat

Alat yang digunakan meliputi timbangan digital (Ohaus), blender (Miyako), moisture analyzer (Ohaus), seperangkat alat gelas (Pyrex), cawan porselin, waterbath, pipet volume $1 \mathrm{~mL}$ (Iwaki), mikroskop (Novel), kapas swab, oven (Memmert), autoklaf (All American), filler (Glasfirn), ose bulat, dan inkubator (Memmert).

\section{Bahan}

Bahan yang digunakan meliputi daun mengkudu, etanol $96 \%$, akuades, alumunim foil, asam asetat, $\mathrm{KOH}$, kloroform, $\mathrm{H}_{2} \mathrm{SO}_{4}$ pekat, $\mathrm{NaCl} 10 \%$, larutan gelatin $1 \%, \mathrm{FeCl}_{3}$, media BAP, kristal violin, larutan iodine, etanol, $\mathrm{NaCl}$ fisiologis 0,9\% (Sanbe Farma), larutan Mc Farland 0.5, kertas cakram $5 \mathrm{~mm}$ (Whatman No.42), paper disk amoksisilin $25 \mu \mathrm{g}$ (Oxoid).

\section{Tahapan Penelitian}

1. Determinasi tanaman. Determinasi dilakukan Laboratorium Taksonomi Tumbuhan Jurusan Biologi-FMIPA Universitas Negeri Semarang (UNNES) untuk mengetahui dan memastikan kebenaran bahwa tanaman yang digunakan adalah spesies Morinda citrifolia $\mathrm{L}$.

2. Ekstraksi daun mengkudu. Ekstraksi dengan metode remaserasi menggunakan 
etanol 96\% dengan perbandingan 1:10. Serbuk sebanyak $200 \mathrm{~g}$ dimasukkan dalam bejana maserasi dan ditambah etanol 96\% sebanyak $1000 \mathrm{~mL}$. Kemudian direndam selama $1 \times 24$ jam dan disaring sehingga didapat filtrat 1 . Hari ke-2 dan ke-3 residu direndam kembali dengan etanol $96 \%$ sebanyak $750 \mathrm{~mL}$ dan $250 \mathrm{~mL}$ selama $1 \times 24$ jam. Campuran simplisia dan pelarut disaring sehingga didapat filtrat 2 dan filtrat 3. Filtrat yang diperoleh disatukan dan dipekatkan di atas waterbath pada suhu $40-50^{\circ} \mathrm{C}$ sampai diperoleh ekstrak kental.

3. Uji bebas etanol. Ekstrak sebanyak $0,5 \mathrm{~g}$ ditambahkan $2 \mathrm{~mL}$ asam asetat dan $2 \mathrm{~mL}$ $\mathrm{H}_{2} \mathrm{SO}_{4}$, kemudian dipanaskan. Reaksi positif bebas etanol ditunjukkan dengan tidak tercium bau ester wangi. Jika masih tercium bau ester wangi, artinya masih ada kandungan etanol yang mengalami esterifikasi (Scroorl, 1998).

\section{Skrining Fitokimia}

a. Senyawa Saponin

Sebanyak $5 \mathrm{~mL}$ larutan uji dipanaskan dan dikocok selama 15 menit sampai terbetuk buih, lalu ditambahkan $\mathrm{HCl} 2 \mathrm{~N}$. Terbentuknya buih yang stabil selama \pm 10 menit menunjukkan adanya kandungan senyawa saponin (Depkes RI, 1989).

b. Senyawa Triterpenoid

Sebanyak $2 \mathrm{~mL}$ larutan uji diuapkan di atas waterbath. Residu yang terbentuk dilarutkan dengan $0,5 \mathrm{~mL}$ kloroform dan $2 \mathrm{~mL} \mathrm{H}_{2} \mathrm{SO}_{4}(\mathrm{p})$ melalui dinding tabung. Terbentuk cincin berwarna kecoklatan atau violet menunjukkan adanya triterpenoid (Ciulei, 1984).

c. Senyawa Tannin

Sebanyak $5 \mathrm{~mL}$ larutan uji dipanaskan di atas waterbath dan ditambahkan 4 tetes $\mathrm{NaCl} 10 \%$ dan larutan gelatin 1\%. Bila terbentuk endapan menunjukkan adanya kandungan tanin (Harborne, 1987).

d. Senyawa Fenol

Sebanyak $2 \mathrm{~mL}$ larutan uji ditambahkan 3 tetes $\mathrm{FeCl}_{3}$ 10\%. Bila terbentuk warna hijau biru kehitaman menunjukkan adanya senyawa fenol (Harborne, 1987).

5. Uji Aktivitas Antibakteri. Bakteri $S$. pyogenes disiapkan dengan mensuspensikan bakteri pada $10 \mathrm{~mL} \mathrm{NaCl} 0,9 \%$ fisiologis sampai tingkat kekeruhan bakteri sama dengan larutan Mc. Farland (konsentrasi sama dengan 1,5 x $108 \mathrm{CFU} / \mathrm{mL})$. Suspensi bakteri $S$. pyogenes diinokulasikan dengan digores pada media BAP menggunakan swab kapas steril, kemudian diamkan selama 5 menit. Cakram steril direndam selama 20 menit pada masing - masing larutan pengujian lalu ditiriskan. Cakram uji yang sudah ditiriskan diletakkan di permukaan medium sesuai dengan posisinya dan dilakukan secara aseptis. Selanjutnya dilakukan inkubasi selama 24 jam pada suhu $37^{\circ} \mathrm{C}$ lalu diamati dan diukur zona hambat yang terbentuk.

\section{Analisa Data}

Data yang diperoleh berupa diameter zona hambat kemudian diuji normalitas dan uji homogenitas. Analisis data dilanjutkan dengan uji Kruskal Wallis dan uji Mann-Whitney dengan tingkat kepercayaan 95\%.

\section{Hasil dan Pembahasan \\ Determinasi tanaman}

Determinasi tanaman bertujuan untuk mengetahui dan memastikan kebenaran dari tanaman yang digunakan. Hasil determinasi menunjukkan bahwa tanaman yang digunakan adalah benar berasal dari spesies Morinda citrifolia L.

\section{Ekstraksi daun mengkudu}

Ekstraksi dengan metode remaserasi bertujuan untuk melarutkan zat-zat dalam simplisia. Maserasi dipilih karena alat yang digunakan sederhana dan pengerjaan mudah (BPOM, 2012). Pelarut menggunakan etanol $96 \%$ yang bersifat universal sehingga dapat menyari senyawa polar maupun semi polar (BPOM, 2013). Senyawa yang diidentifikasi terdiri dari senyawa saponin, triterpenoid, tanin dan fenol. Senyawa saponin memiliki kelarutan larut dalam etanol dan air (Kar, 2014). Senyawa triterpenoid merupakan senyawa non polar namun juga larut dalam air. Senyawa tanin larut dalam air dan pelarut organik seperti etanol (Ismarani, 2012). Senyawa fenol memiliki kelarutan dalam air dan pelarut polar lain (Poedjaji \& Titin, 2009). Hasil parameter uji kualitas ekstrak etanolik daun mengkudu dapat dilihat pada Tabel I berikut. 
Uji Aktivitas Antibakteri Ekstrak Etanolik Daun Mengkudu

Tabel I. Parameter Kualitas

Ekstrak Etanolik Daun Mengkudu

\begin{tabular}{lc}
\multicolumn{1}{c}{ Parameter } & Hasil Pengujian \\
\hline Organoleptis & $\begin{array}{l}\text { konsistensi kental, bau } \\
\text { khas, rasa pahit berwarna } \\
\text { hijau kehitaman }\end{array}$ \\
Rendemen & $21,71 \% \mathrm{~b} / \mathrm{b}$ \\
Susut & $6,31 \%$ \\
Pengeringan &
\end{tabular}

Skrining Fitokimia. Skrining fitokimia dilakukan untuk mengetahui golongan senyawa metabolit sekunder yang terkandung dalam ekstrak etanolik daun mengkudu. Menurut Aryadi (2014), ekstrak daun mengkudu mengandung senyawa saponin, triterpenoid, tanin dan fenol yang berpotensi sebagai antibakteri. Hasil skrining fitokimia ekstrak etanolik daun mengkudu dapat dilihat pada Tabel II.

Tabel II. Skrining Fitokimia Ekstrak Etanolik daun Mengkudu

\begin{tabular}{lllc}
\hline Senyawa & Sebelum & Sesudah & Ket \\
\hline Saponin & $\begin{array}{l}\text { Tidak } \\
\text { terdapat buih }\end{array}$ & Timbul Buih & + \\
Triterpen & $\begin{array}{l}\text { Hijau } \\
\text { kehitaman }\end{array}$ & Cincin coklat & + \\
Tanin & Hijau coklat & Endapam & + \\
Fenol & Hijau coklat & Hijau hitam & + \\
\hline
\end{tabular}

\section{Uji Aktivitas Antibakteri}

Pengujian aktivitas antibakteri menggunakan metode Kirby Bauer, yaitu penghambatan terhadap pertumbuhan mikroorganisme dengan mengamati timbulnya zona hambat. Metode Kirby Bauer dipilih karena mudah dalam menyesuaikan konsentrasi ekstrak, alat yang digunakan sederhana, hasil uji dapat diketahui dalam waktu yang relatif cepat serta mudah dalam proses isolasi pada media. Blood Agar Plate (BAP) merupakan media padat dan media diferensial. Bakteri S. pyogenes pada media BAP menunjukkan hemolisis berupa zona bening disekitar koloni bakteri sehingga disebut sebagai Streptococcus $\beta$ hemoliticus (Elliot dkk, 2013).

Dalam penelitian uji aktivitas antibakteri ekstrak etanolik daun mengkudu menggunakan konsentrasi 1,25\%, 2,50\% dan $5,00 \%(\mathrm{~b} / \mathrm{v})$. Konsentrasi tersebut didapatkan dari penelitian Aryadi (2014) dimana pada konsentrasi 10\% ekstrak daun mengkudu menimbulkan zona hambat kuat sebesar $16 \mathrm{~mm}$, sehingga dilakukan pengecilan konsentrasi untuk mendapatkan Kadar Hambat Minimal (KHM). Hasil pengujian aktivitas antibakteri dapat dilihat pada Gambar 1.

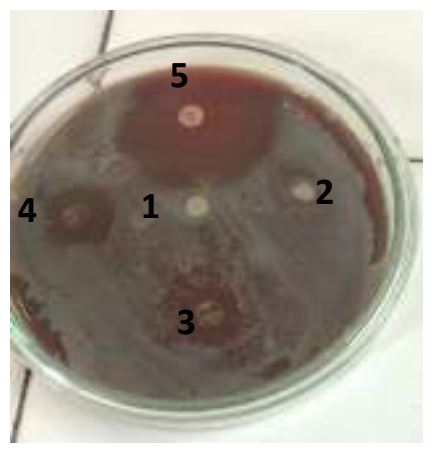

Gambar 1. Hasil Aktivitas Antibakteri Ekstrak Etanolik Daun Mengkudu

Keterangan:

1. Kontrol negatif (akuades steril)

2. Ekstrak daun mengkudu 1,25\%

3. Ekstrak daun mengkudu $2,50 \%$

4. Ekstrak daun mengkudu 5,00\%

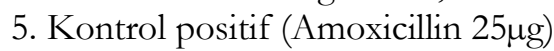

Data hasil pengukuran zona hambat ekstrak etanolik daun mengkudu konsentrasi $1,25 \% ; 2,50 \%$ dan $5,00 \%$; akuades sebagai kontrol negatif serta amoksilin sebagai kontrol positif dapat dilihat pada Tabel III berikut.

Tabel III. Hasil Rerata Diameter Zona Hambat Ekstrak Etanolik Daun Mengkudu

\begin{tabular}{|l|c|c|c|c|}
\hline \multirow{2}{*}{ Perlakuan } & \multicolumn{3}{|c|}{ Diameter Zona Hambat } & Rerata \\
\cline { 2 - 5 } & $\mathbf{1}$ & $\mathbf{2}$ & $\mathbf{3}$ & \\
\hline $\begin{array}{l}\text { Kontrol negatif } \\
\text { (akuades steril) }\end{array}$ & - & - & - & - \\
\hline $\begin{array}{l}\text { Ekstrak daun } \\
\text { mengkudu } \\
1,25 \%\end{array}$ & - & - & - & - \\
\hline $\begin{array}{l}\text { Ekstrak daun } \\
\text { mengkudu } \\
2,50 \%\end{array}$ & 5,50 & 6,00 & 6,00 & 5,83 \\
\hline $\begin{array}{l}\text { Ekstrak daun } \\
\text { mengkudu } \\
5,00 \%\end{array}$ & 7,50 & 10,0 & 10,0 & 9,17 \\
\hline $\begin{array}{l}\text { Kontrol positif } \\
\text { (Amoxicillin } \\
25 \mu g)\end{array}$ & 33,00 & 33,00 & 33,00 & 33 \\
\hline
\end{tabular}


Pada konsentrasi 2,50\% menimbulkan zona hambat sebesar $5,8 \mathrm{~mm}$ yang termasuk berdaya hambat sedang. Sedangkan pada konsentrasi $1,25 \%$ tidak menimbulkan zona hambat. Hal ini menunjukkan bahwa KHM daun mengkudu terhadap bakteri $S$. pyogenes ada pada konsentrasi 2,50\%. Kontrol negatif (akuades steril) tidak menimbulkan zona hambat sehingga dapat diketahui bahwa kontrol negatif tidak memiliki aktivitas antibakteri. Kontrol positif pada penelitian ini menggunakan paperdisk amoksisilin $25 \mu \mathrm{g}$ yang hambat antara 5-10 $\mathrm{mm}$ dan lemah apabila ratarata diameter zona hambat $\leq 5 \mathrm{~mm}$ (Davis \& Stout, 1971).

Data hasil penguiian daya hambat antibakteri ekstrak etanolik daun mengkudu terhadap bakteri $S$. pyogenes dianalisis menggunakan uji statistik. Tahap awal pengujian dengan menggunakan uji normalitas (SaphiroWilk) dan uji homogenitas. Selanjutnya uji Kruskall-Wallis dilakukan, hasil didapatkan nilai signifikan $(\mathrm{p}<0,05)$ menunjukkan adanya perbedaan bermakna, artinya dengan konsentrasi yang berbeda dapat mempengaruhi zona hambat yang terbentuk. Analisa dilanjutkan dengan uji Mann-Whitney dengan tujuan untuk mengetahui adanya perbedaan signifikan dari setiap perlakuan. Hasil statistik dapat dilihat pada Gambar 2 berikut.

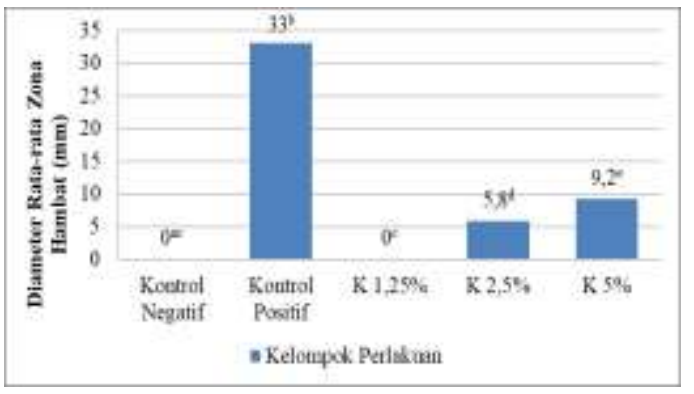

\section{Gambar 2. Grafik Zona Hambat Ekstrak Etanolik Mengkudu Terhadap Bakteri S. Pyogenes}

Keterangan: angka menunjukkan rata-rata zona hambat dan superskrip huruf yang sama menunjukkan hasil perlakuan yang berbeda tidak bermakna ( $>>0,05)$ dengan Uji Man-Withney

Grafik zona hambat ekstrak etanolik daun mengkudu menunjukkan bahwa semakin besar konsentrasi ekstrak etanolik daun mengkudu, maka semakin tinggi kemampuan ekstrak dalam menghambat pertumbuhan termasuk antibiotik berspektrum luas. Amoksisilin dapat membunuh bakteri gram positif maupun gram negatif dengan mekanisme kerja menghambat sintesis dinding sel bakteri (Tjay \& Rahardja, 2013). Diameter zona hambat pada kontrol positif sebesar $33 \mathrm{~mm}$ yang termasuk berdaya sangat kuat. Antibakteri dikatakan memilik daya sangat kuat apabila memiliki nilai rata-rata diameter zona hambat $>20 \mathrm{~mm}$, kuat apabila rata-rata diameter zona hambat $10-20 \mathrm{~mm}$, sedang apabila rata-rata diameter zona

bakteri dan sebaliknya. Hal ini disebabkan daya antibakteri yang terdapat di dalam ekstrak berbanding lurus dengan konsentrasi ekstrak, sehingga kemampuan ekstrak dalam menghambat pertumbuhan bakteri semakin besar.

Menurut Aryadi (2014), senyawa aktif pada daun mengkudu yang dapat menghambat pertumbuhan bakteri, yaitu saponin, triterpenoid, tanin dan fenol. Zat aktif tersebut bekerja dengan mekanisme yang berbeda-beda. Mekanisme kerja dari saponin adalah dengan mengganggu permeabilitas membran sel mikroba, sehingga mengakibatkan kerusakan membrane sel dan menyebabkan keluarnya berbagai komponen penting dari dalam sel bakteri, seperti protein, asam nukleat, nukleutida, dan lain-lain (Khasanah, 2014). Mekanisme kerja triterpenoid adalah dengan pengerusakan membran sel bakteri oleh senyawa lipofilik (Cowan, 1999). Mekanisme kerja dari senyawa tannin adalah dengan menginaktifkan enzim dan mengganggu transport protein pada lapisan dinding sel bakteri. Tanin mempunyai target pada polipeptida pada dinding sel dan pembentukkan menjadi kurang sempurna, sehingga menyebabkan sel bakteri lisis karena tekanan osmotik maupun fisik yang menyebabkan kematian sel bakteri (Sari, 2011). Mekanisme kerja senyawa fenol sebagai antibakteri yaitu dengan mendenaturasi ikatan protein pada membran sel sehingga membran sel lisis dan memungkinkan fenol menembus ke dalam sitoplasma yang menyebabkan bakteri tidak berkembang (Sulistyawati \& Mulyati, 2009).

\section{Simpulan}

1. Ekstrak etanolik daun mengkudu mempunyai aktivitas antibakteri terhadap bakteri Streptococcus pyogenes. 
Uji Aktivitas Antibakteri Ekstrak Etanolik Daun Mengkudu (Morinda Citrifolia L.) Terhadap Bakteri Streptococcus Pyogenes secara In Vitro

2. Konsentrasi Hambat Minimum (KHM) ekstrak etanolik daun mengkudu terhadap bakteri Streptococcus pyogenes didapatkan pada konsentrasi $2,5 \%$.

\section{Ucapan Terima Kasih}

Fakultas Kedokteran Universitas Diponegoro bagian mikrobiologi atas determinasi biakan stain bakteri S. pyogenes.

\section{Daftar Pustaka}

Aryadi, I.G.I.P., 2014. Pengaruh Ekstrak Daun Mengkudu (Morinda citrifolia L.) terhadap Pertumbuhan Staphylococcus aureus Sebagai Penyebab Abses Periodontal secara In Vitro. Skripsi Fakultas Kedokteran Gigi. Universitas Mahasaraswati Denpasar: Denpasar.

BPOM RI., 2012. Pedoman Teknologi Formulasi Sediaan Berbasis Ekstrak. Badan Pengawas Obat dan Makanan Republik Indonesia. Jakarta.

BPOM RI., 2013. Pedoman Teknologi Formulasi Sediaan Berbasis Ekstrak, Volume II. Jakarta : Badan Pengawas Obat dan Makanan Republik Indonesia.

Ciulei, J., 1984. Metodolgy for Analysis of Vegetable and Drugs. Bucharest Rumania: Faculty of Pharmacy, pp 11-26

Cowan, M.M., 1999. Plant Products as Antimicrobial Agents. Clinical Microbiology Reviews; 12: 564-582.

Davis \& Stout., 1971. Disc Plate Method Of Microbiological Antibiotic Essay. Journal Of Microbiology. Vol 22 No 4.

Depkes RI., 1989. Materia Medika Indonesia Jilid III. Direktorat Pengawasan Obat

Diassanti, A., 2011. Uji Ekstrak Etanol Daun Mengkudu (Morinda citrifolia) sebagai Antimikroba terhadap Methycillin Resistant Stapbylococcus aureus (MRSA) Secara In Vitro.Skripsi. Universitas Brawijaya: Malang.

Dipiro, J.T., Robert, L., Talbert, G.C., Yee, G.R., Matske, B.G., Wells, L., \& Michael, P., 2015. Pharmacotherapy Handbook $9^{\text {th }}$ ed. USA: The Mc. Graw Hill Company.

Elliot, T., Worthington, T., Osman, H., \& Gill, M., 2013. Mikrobiologi Kedokteran \& Infeksi. Jakarta: EGC.
Harborne, J.B., 1987. Metode Fitokimia: Penuntun Cara Modern Menganalisa Tumbuban. ITB, Bandung.

Harborne, J.B., 1998. Phytochemical Methods A Guide to Modern Techniques of Plant Analysis. Chapman \& Hall: London.

Ismarani., 2012. Potensi Senyawa Tannin Dalam Menunjang Produksi Rumah Lingkungan. Jurnal Agribisnis dan Pengembangan Wilayah. Vol. 3

Kar, A., 2014. Farmakognosi \& Farmakobioteknologi. Jakarta: EGC. Vol 2.

Khasanah, L. U., Utami, R., Anandhito, B. K., \& Nugraheni, A.E., 2014, Pengaruh Perlakuan pendahuluan Fermentasi Padat Dan Fermentasi Cair Terhadap Rendemen Dan Karakteristik Mutu Minyak Atsiri Daun Kayu Manis, Sebelas Maret, Surakarta, Jurnal Agritech, Vol. 34, No. 1.

Khopkar, S.M., 2008. Konsep Dasar Kimia Analitik. Jakarta: Universitas Indonesia Press.

Kuswandi., 2016. Resistensi Antibotika. Yogyakarta: Penerbit Grafika Indah.

Nagel, P., \& Gurkov, R., 2012. Dasar Dasar Imu THT, Ed. 2. Jakarta: EGC.

Pratiwi, S.T., 2008. Mikrobiologi Farmasi. Jakarta: Penerbit Erlangga.

Poedjiaji, A, \& Supriyanti, F.M. Titin., 2009. Dasar-Dasar Biokimia. Jakarta: Penerbit Universitas Indonesia.

Sari, F.P., \& Sari., 2011. Ekstraksi Zat Aktif Antimikroba dari Tanaman Yodium (Jatropha multifida Linn) sebgai Bahan Baku Alternatif Antibiotik Alami. Semarang: Fakultas Teknik Universitas Diponegoro.

Schoorl., 1998. Materi Pelengkap Kemurnian Cara Pemisahan Obat. Yogyakarta: Gajah Mada University Press.

Sulistyawati, D., \& Mulyati, S., 2009. Uji Aktivitas Antijamur Infusa Daun Jambu Mete (Anacardium occidentale L.) terhadap Candida albicans. Jurnal Biomedika 2(1):47-51.

Tjay, T.H, \& Rahardja, K., 2013. Obat-Obat Penting. Jakarta : PT Elex Media Kompetindo Gramedia. 